\title{
O Brasil bateu no piso?
}

\section{Carlos Pinkusfeld Bastos ${ }^{1}$ \\ Gabriel Ferraz Aidar ${ }^{2}$}

\section{Introdução}

Após oito trimestres seguidos de retração desde o início de 2015, o Produto Interno Bruto Brasileiro (PIB) parou de cair em 2017, registrando modestas taxas de crescimento nos três primeiros trimestres de 2017. A variação acumulada alcançou taxa negativa de $4,24 \%$ no segundo trimestre de 2016, enquanto no terceiro trimestre de 2017 ainda permanece negativa, $0,17 \%$, ainda que apontando para o agregado do ano um tendência de pequeno crescimento. A pergunta se a economia bateu no seu "piso" ou mesmo qual o sentido de tal conceito, ou ideia, só pode ser discutida uma vez que se estabeleçam claramente os parâmetros teóricos de tal debate.

Certamente, para a abordagem marginalista, a ideia do piso, aliás de uma convergência de piso e teto para a posição de pleno emprego dos fatores de produção, é a tendência normal da economia, a ser alcançada quando todas as rigidezes e intervenções que interfiram no funcionamento normal dos "mecanismos de mercado" sejam eliminadas.

O presente texto adotará como perspectiva teórica a determinação do nível de produto e emprego segundo o Princípio da Demanda Efetiva, inclusive assumindo sua validade como determinante do crescimento de longo prazo. Partindo-se deste referencial, tal piso não é teoricamente garantido, dependendo do desempenho dos componentes autônomos da demanda efetivamente dispendida por agentes privados e governo dentro da economia de um país e da demanda do resto do mundo através das exportações. A utilização dos fatores de produção, no curto prazo e a capacidade produtiva no longo, ou seja, a oferta agregada efetiva e potencial, responderiam a tais decisões de demanda.

Assim, a avaliação de tendências da economia depende de uma série de condições histórico, sociopolíticas, institucionais nacionais e internacionais. Dadas essa multiplicidade de fatores a serem examinados, numa primeira aproximação, é interessante anotar o que nos diz a experiência histórica.

O episódio mais recente de aguda queda cíclica se deu na chamada Grande Recessão que teve como origem a crise do subprime dos EUA, cujo período mais grave se inicia após a quebra do Lehman Brothers em 15 de setembro de 2008. Neste caso, a queda não foi tão pronunciada, graças a uma maciça intervenção pública, principalmente para o socorro dos sistemas financeiros internacionais. De maneira geral, as recuperações econômicas, principalmente na Europa, foram bastante lentas. Mesmo nos EUA a velocidade de recuperação foi inferior às reversões cíclicas do pós guerra ${ }^{3}$. 0 caso mais dramático de queda profunda do PIB per capita se deu na Grécia. Este fato, entretanto, é explicado por imposições de política econômica aplicadas pela chamada "Troika" (FMI, Comissão Europeia e Banco Central Europeu), ou seja, foi resultado de uma condição sociopolítica, ou, mais especificamente, geopolítica, muito particular ${ }^{4}$.

\footnotetext{
${ }^{1}$ Professor do IE/UFRJ, pinkusfeld@gmail.com

${ }^{2}$ Doutorado do IE/UFRJ, gabriel.aidar@gmail.com

${ }^{3}$ Ver Bivens (2016)

${ }^{4} \mathrm{Na} Z$ Zona do Euro, diferentemente de países como o Brasil, por exemplo, a liquidez dos títulos públicos

é garantida por uma entidade supranacional (Banco Central Europeu) o que inviabiliza com que os
} 
Outro caso, ainda mais dramático de queda pronunciada do PIB por um prazo de tempo relativamente extenso ${ }^{5}$ é o da Rússia. Entre 1993 e 1998, segundo dados do WEO/FMI, o PIB desse país caiu $30 \%$. Deve-se anotar o cenário particularmente dramático, caracterizado pelo conturbado fim do regime centralmente planejado e o surgimento de uma economia de mercado na Rússia, um processo que incluiu "reorganização" territorial e eliminação da área de comércio com os países da Europa Oriental. Mesmo assim, cerca de uma década depois da desintegração da antiga URSS, a Rússia começa a empreender uma vigorosa recuperação, ainda que partindo de níveis de produto muito baixos.

Essa muito sucinta discussão sobre algumas poucas experiências históricas nos levam a pensar se não haveria, como um "inverso" do clássico limite político ao pleno emprego de Kalecki (1943); algum limite político, ou social, à debacle econômica.

Como ilustrado, os casos mais dramáticos contaram com mudanças políticosinstitucionais significativas. É de se supor que quando isso não ocorre, há uma inércia institucional maior, ou seja: uma não ruptura da institucionalidade pré-crise, acaba sendo favorável à existência de um piso que contribua para evitar quedas persistentes do produto, ainda que em nada justifiquem uma retomada vigorosa. Com base no arcabouço da demanda efetiva, esse piso naturalmente deve estar associado ao desempenho de algum componente autônomo da demanda e, em especial, domesticamente, ao gasto público.

É esta hipótese teórica que pretendemos analisar no restante desta nota. Basicamente, busca-se apontar que a aparente estabilização do produto, seria resultado de uma inércia institucional, ou a operação de instrumentos de incentivo à demanda, relativamente "automáticos" ou ao menos não discricionários. Ironicamente, uma das poucas bases de sustentação de um governo com índices de aprovação extremamente reduzidos, qual seja, a melhoria de indicadores macroeconômicos, é resultado, como veremos, de fatores institucionais que são alvo de críticas e propostas de reformas pelo próprio governo.

A demonstração de tal hipótese se fará com a apresentação de dados macroeconômicos partindo de um nível mais agregado possível e depois a análise de componentes de demanda e de desempenho da oferta, com algum grau de desagregação setorial. Finalmente, examinamos os condicionantes do comportamento dos componentes da demanda efetiva e suas perspectivas no médio prazo.

\section{Quadro geral do desempenho do nível de atividade}

Após oito trimestres de queda contínua, O PIB trimestral sai do "vermelho" apresentando taxas positivas de crescimento nos três primeiros trimestres de 2017, como pode-se observar nos Gráficos 1 e 2. Não se deve desprezar a dimensão da queda do produto experimentada entre 2015 e 2016. Ela é a maior combinação histórica no Brasil e se mostra ainda mais dramática em termos de renda per capita uma vez que observamos que de 2014 até o primeiro semestre de 2017 , o PIB per capita se reduziu em $10,4 \%$.

bancos centrais nacionais atuem para garantir a liquidez dos mercados de títulos domésticos. Para uma descrição dessa relação no Brasil: Resende (2009) e Pimentel e Serrano (2016).

\footnotetext{
${ }^{5}$ Vale anotar que não estamos levando em consideração eventos que refletem efeitos devastadores de guerras ou epidemias.
} 
Gráfico 1: Série Encadeada do PIB (sem aj. sazonal) - 40 tri/2013=100

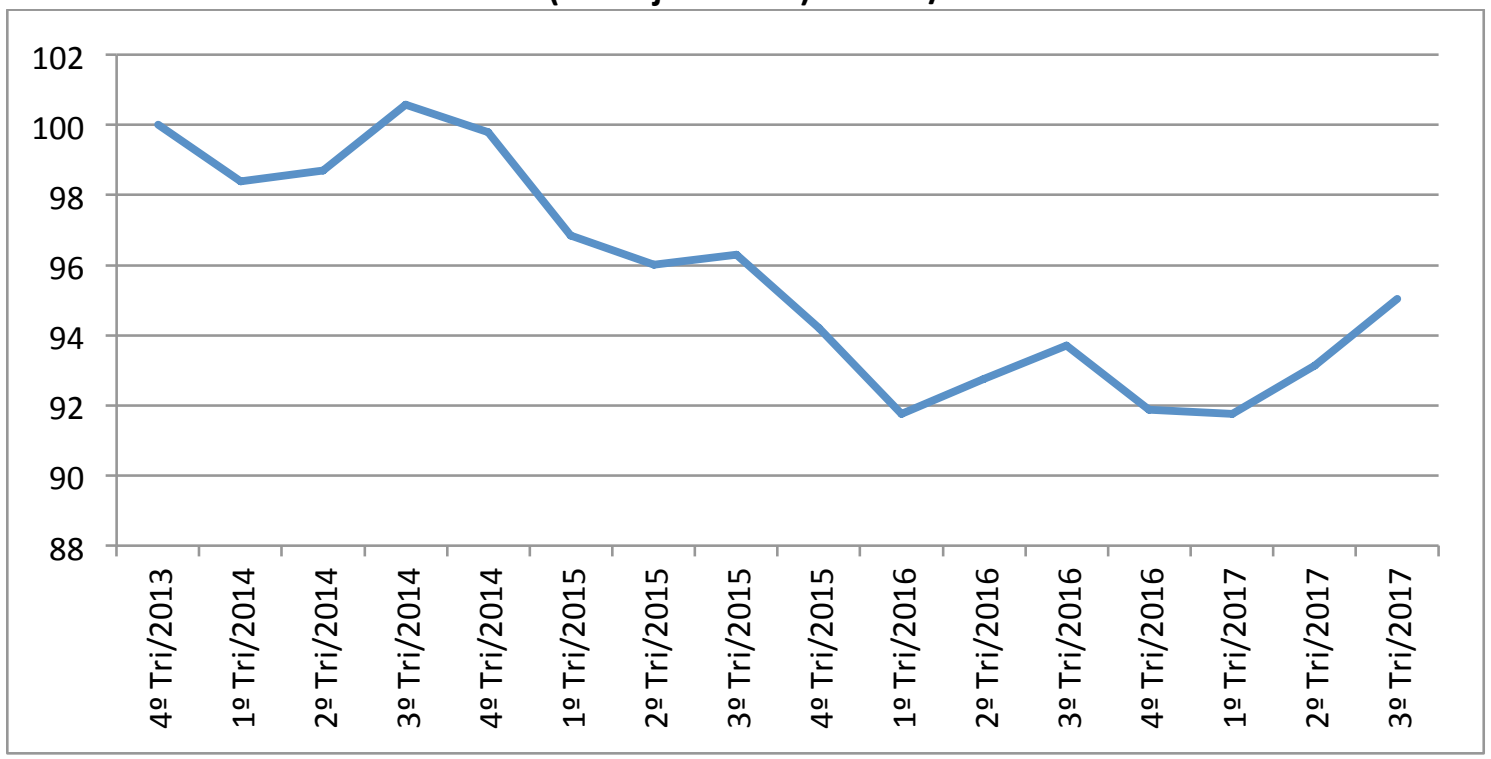

Fonte: IBGE. Elaboração Própria

Gráfico 2: Variação (\%) do PIB - Contas Nacionais Trimestrais

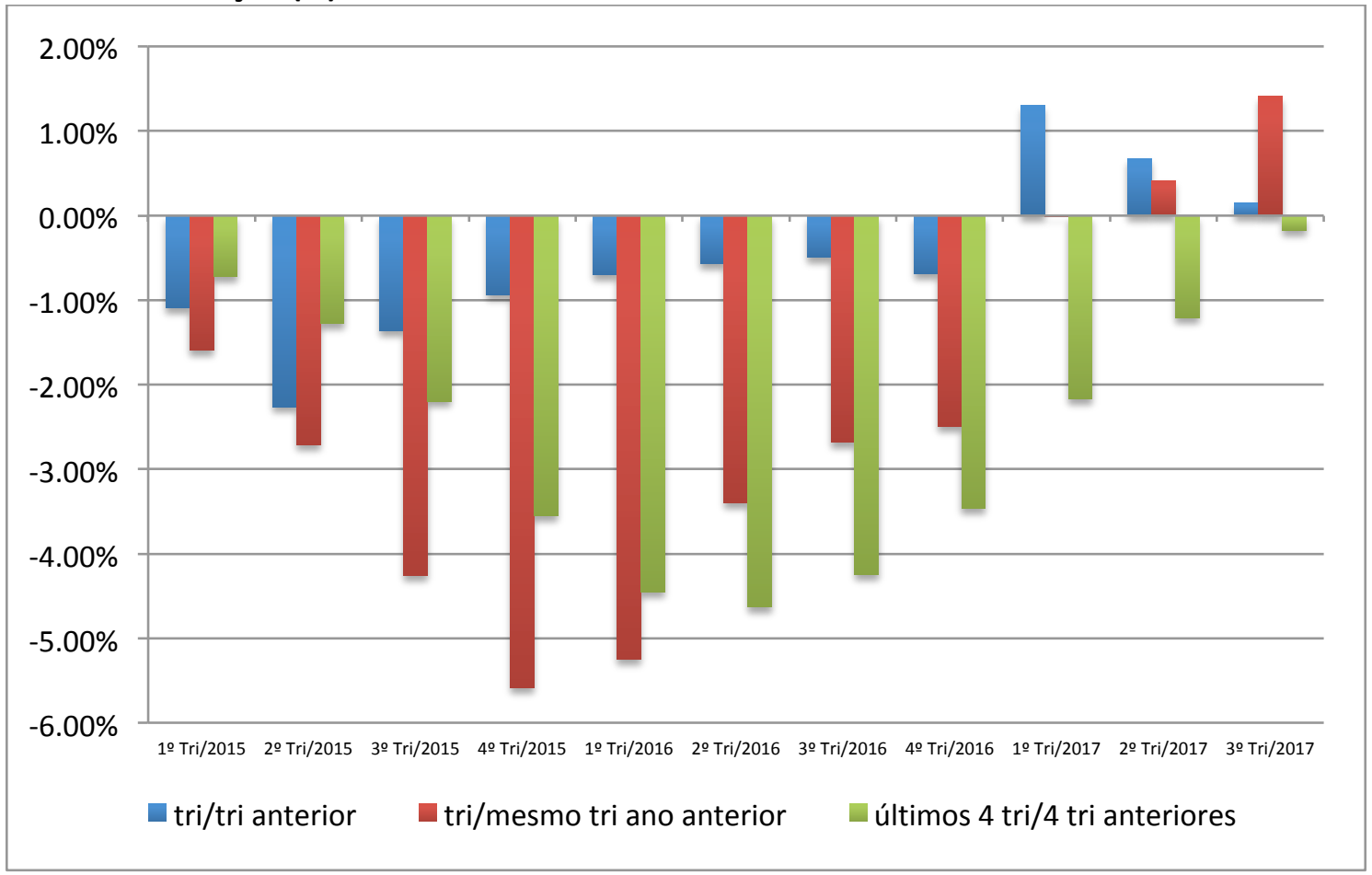

Fonte: IBGE. Elaboração Própria

Curiosamente, apesar do dado do primeiro trimestre ser mais expressivo em termos de crescimento contra o trimestre anterior que o do segundo e terceiro (e não quando comparado contra o mesmo trimestre do ano anterior) no geral pode-se considerar que estes apresentam um desempenho que poderia ser considerado melhor. Em relação ao segundo trimestre foi a primeira vez, desde o início de 2014, que a variação do PIB foi positiva na comparação interanual, fato este que se repete no terceiro trimestre de 2017.

Inicialmente, a maior taxa do primeiro trimestre de 2017 é obtida quando calculada contra o trimestre anterior, que por sua vez foi um período de forte retração da atividade econômica. Contra o mesmo trimestre no ano de 2016 o resultado ainda foi negativo. Outro 
fator importante diz respeito aos componentes da demanda: no primeiro trimestre de 2017, fora as exportações, todos os componentes de demanda tiveram contração. Ainda, em relação a este trimestre, Lara, Serrano e Summa (2017) mostram que a acumulação de estoques, possivelmente indesejados, pode explicar um desempenho menos pior pelo lado da demanda. Conforme argumentam os autores, o crescimento dos estoques no primeiro trimestre deste ano foi muito superior à média histórica. No entanto, o comportamento dos componentes da demanda efetiva não pareceu corroborar o acúmulo de estoques no início do ano. Ou seja: não pareceu ter havido uma elevação da demanda agregada que justificasse uma elevação/correção dos estoques desejados.

Já no segundo e terceiros trimestres de 2017, além de um desempenho melhor contra o mesmo período do ano anterior, o principal componente da demanda agregada, o consumo, teve uma taxa positiva de variação, com crescimento no terceiro trimestre, tomando-se o índice encadeado, de 2,22\%. Especificamente, o primeiro trimestre de 2017 apresentou a primeira variação positiva desde 2014 e, adicionalmente, nesse trimestre a variação negativa dos estoques tendem a mostrar que houve uma correção em relação ao crescimento no trimestre anterior. Tomando em conjunto os três trimestres observa-se uma quase estabilidade, com crescimento anual de 0,6\%.

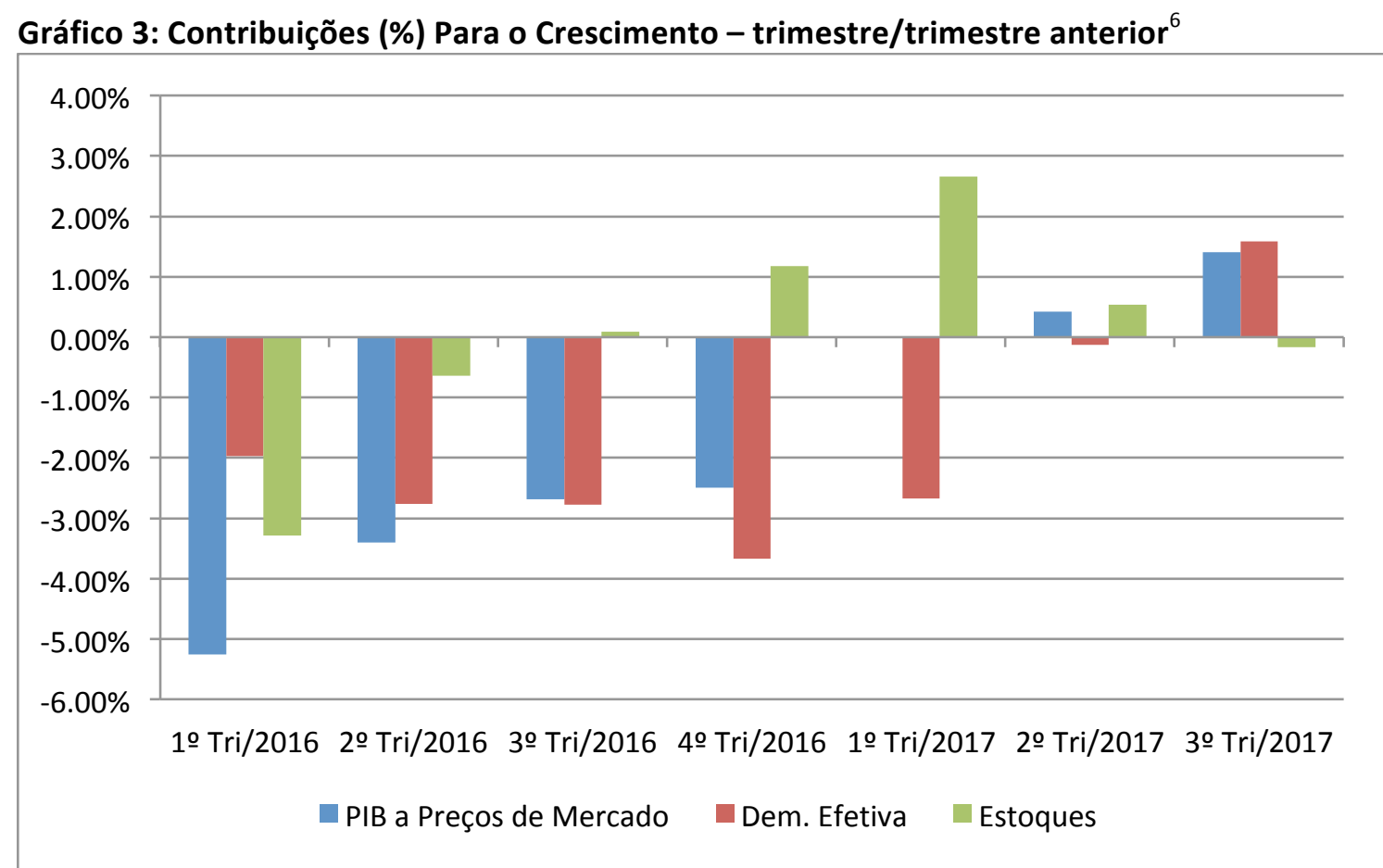

Fonte: IBGE. Elaboração Própria

Em resumo, dos dados do PIB tiramos uma trajetória de recuperação frente principalmente ao mergulho recessivo do segundo semestre de 2016. Alguns indicadores pelo lado da oferta confirmam a hipótese de fim da queda e leve recuperação da atividade econômica em 2017. O Gráfico 4 apresenta o desempenho das atividades, indústria e serviços, que perfazem mais de $90 \%$ da oferta.

\footnotetext{
${ }^{6}$ Utilizou-se a mesma metodologia utilizada em Summa, Lara e Serrano (2017).
} 
Gráfico 4: Atividade - Índice de Base Fixa (com aj. sazonal)

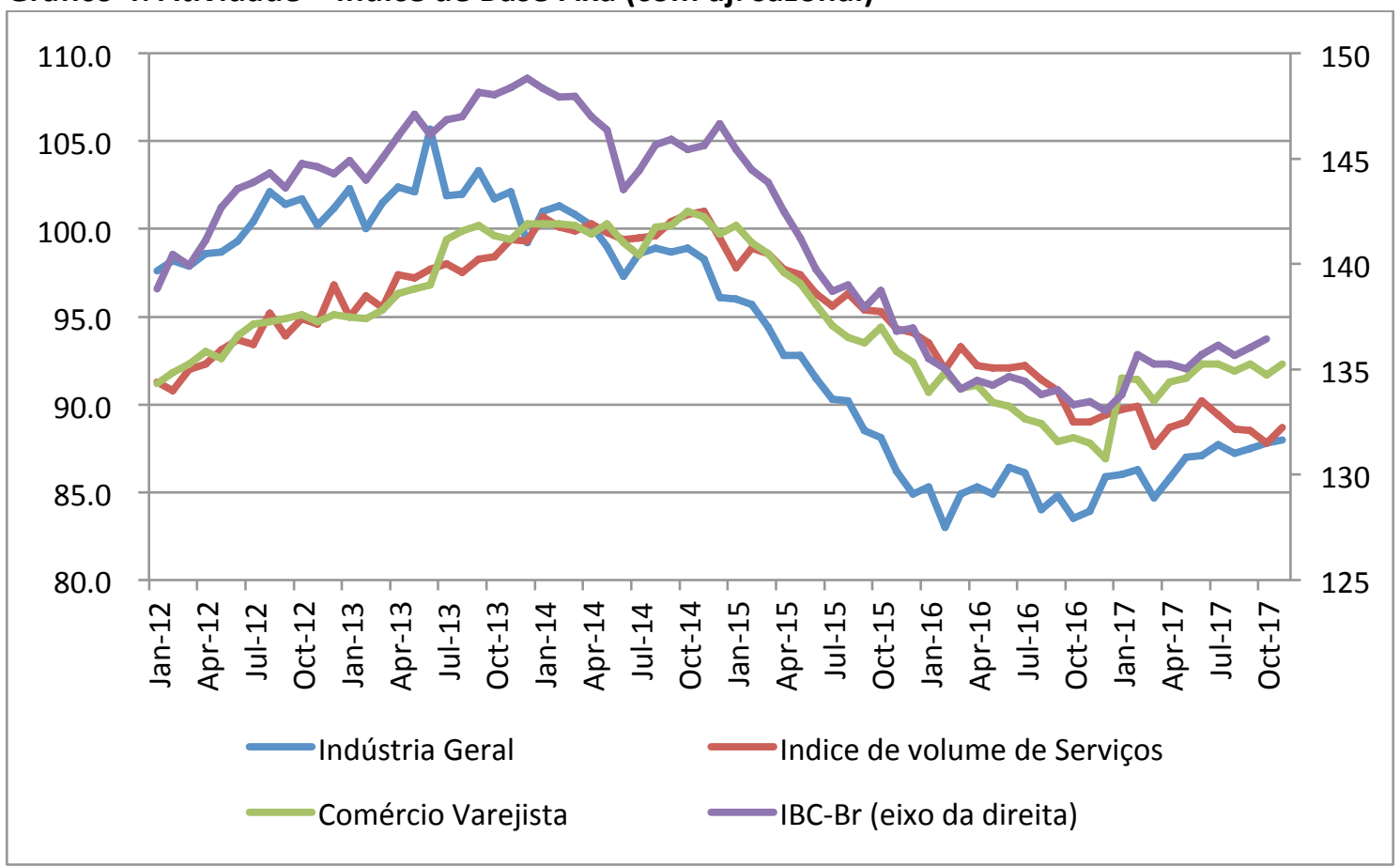

Fonte: IBGE e BCB. Elaboração Própria

Tanto serviços como indústria contam uma história semelhante ainda que não coincidente em sua temporalidade: a indústria foi o primeiro setor a entrar no terreno negativo em termos de taxas de variação e também a demorar mais a encontrar seu valor mais baixo: 34 meses. A queda entre pico e vale chegou a quase 20\%, mas partir de 2016, o setor apresenta uma leve tendência de recuperação, ainda assim muito limitada: entre o vale de alcançado em fevereiro de 2016 e novembro de 2017, a recuperação atingiu apenas 6\%.

Os dados de serviços e comércio, até pela superposição estatística, apresentam comportamento semelhante. Demoraram mais a começar a cair, a partir de um pico de atividade (Outubro e Novembro de 2014 para o comércio e serviços respectivamente), e registraram uma duração entre pico e vale mais curta: 28 meses para serviços e 26 para comércio. A recuperação do comércio a partir do vale é semelhante a da indústria num período bem mais curto de tempo, resultado que é consistente com os dados agregados de melhoria do consumo no segundo e terceiro trimestres. Já em relação aos serviços não se pode falar claramente nem de uma tendência de leve recuperação; os dados disponíveis até o momento da entrega deste artigo apontam apenas uma estabilidade, sendo que após o crescimento do primeiro semestre, os três últimos meses encerrados em setembro trouxeram uma variação negativa.

Como variável chave, não apenas pelo seu impacto no consumo como também pelos seus fortes impactos sociais e políticos, é importante analisar a variável emprego. Existem duas fontes de dados relevantes: o Cadastro Geral de Empregado e Desempregado (CAGED) e a PNAD contínua. O primeiro reporta dados do mercado formal enquanto o segundo cobre todas as ocupações, incluindo as atividades informais.

O Gráfico 5, mostra que no acumulado de doze meses o saldo de criação de empregos chegou ao seu vale em março de 2016. A partir de então a tendência é de melhora, porém permanecendo o acumulado no terreno negativo. Este saldo só entra no terreno positivo a partir de abril de 2017, entretanto, em valores historicamente bastante baixos. Para se ter uma base de comparação: a média desses seis meses sequencialmente positivos de 2017 foi 
de aproximadamente 35.000 postos de trabalho, enquanto que em 2014, quando a economia já apresentava claros sinais de desaceleração, no último período em que o emprego cresceu persistentemente por seis meses, a média entre abril e outubro daquele anos foi mais que o dobro da registrada em 2017.

\section{Gráfico 5: Emprego - CAGED e PNAD Contínua}

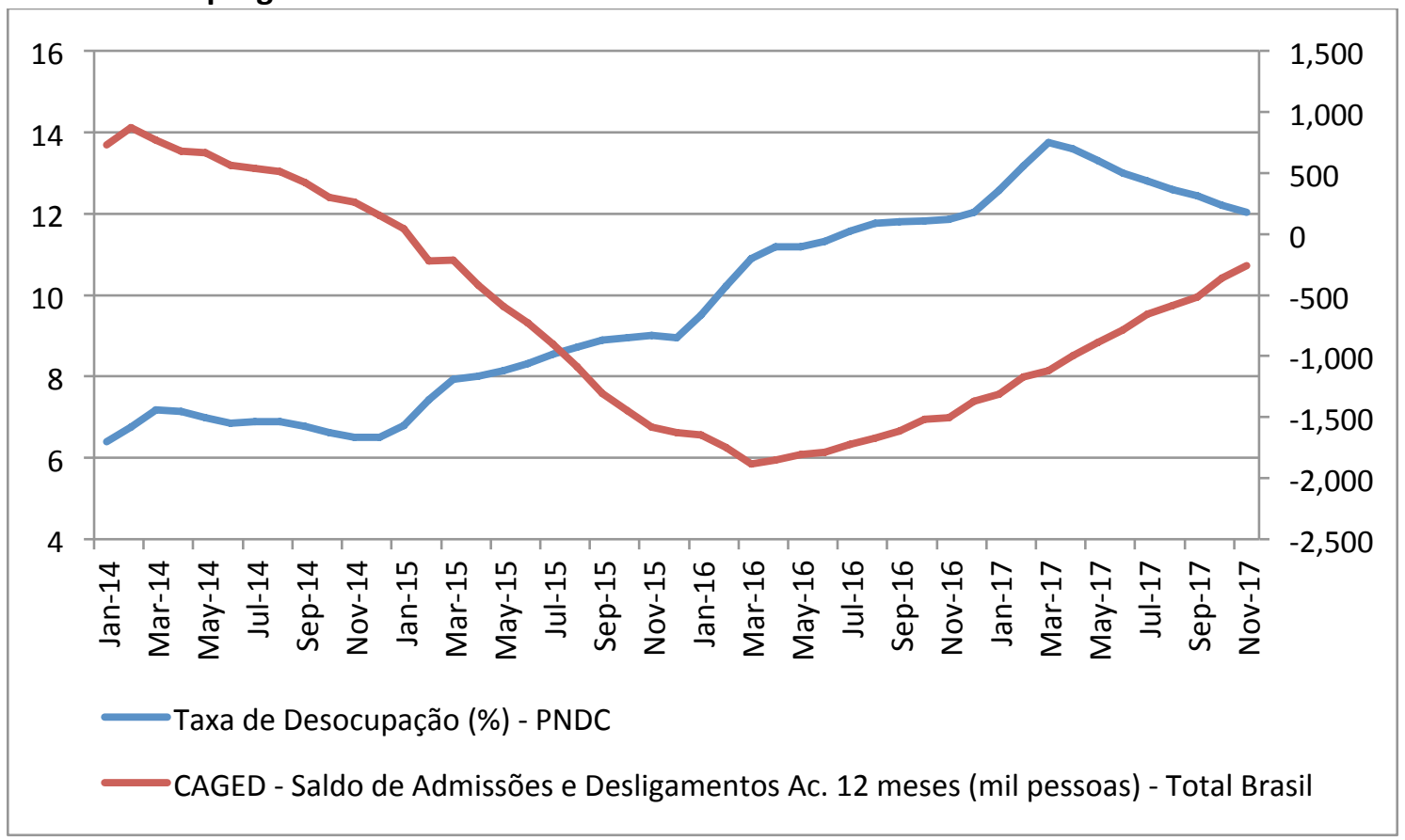

Fonte: Ministério do Trabalho/CAGED e IBGE. Elaboração Própria

Os dados da PNAD contínua confirmam o quadro do emprego formal descrito pela CAGED. Março de 2017 é um ponto de inflexão a partir de um pico de desemprego de $13,7 \%$ e até Outubro este valor recuou para $12,4 \%$. O dado relevante que a PNAD nos trás é uma certa piora das condições estruturas do mercado de trabalho, ou seja, um crescimento da participação de trabalho sem carteira e por contra própria no total do emprego, sendo interessante notar que a tendência já é perceptível desde 2014. A participação dos segmentos "empregador", "conta própria" e "trabalhador familiar auxiliar", todos sem carteira de trabalho, aumentou de $41,4 \%$ da força de trabalho, em outubro de 2014 , para $44,4 \%$ em novembro de 2017.

Finalmente, quanto ao mercado de trabalho a outra variável relevante é o salário real. Tanto no indicador do salário real de novas admissões (CAGED) quanto no indicador mais geral fornecido pela PNAD Contínua (rendimento médio real de todos os trabalhos), há aumento dessa variável em 2017. Assim, pelo dado da CAGED, na média entre janeiro a setembro deste ano versus o mesmo período do anterior, há aumento de $4 \%$ do rendimento real. Já a média para o mesmo período da PNAD aponta crescimento de $2,1 \%$ do rendimento real.

\section{Componentes da demanda agregada}

\subsection{Exportações}

$\mathrm{Na}$ introdução deste texto anotamos que procuraríamos analisar a dinâmica da economia segundo os componentes da demanda efetiva, especificamente os gastos autônomos, que poderiam interromper a trajetória de retração da economia iniciada em 2014 e que se aprofunda a partir de 2015. Indicamos também que, numa economia cujo nível de produto é determinado pela demanda efetiva, em princípio não haveria um piso dado pela oferta. No entanto, historicamente, verifica-se que mesmo profundas depressões encontram 
pontos de virada que refletem algum tipo de resistência histórico/institucional à deterioração social advinda da queda do nível de atividade.

Um componente de demanda que pode ter um papel muito importante em qualquer recuperação são as exportações e neste caso particular não se pode falar exclusivamente de alguma característica institucional doméstica. Em verdade, as condições, ou melhor, mudanças nas condições internacionais, podem ter um efeito contrário a opções de política econômica contracionistas, como ocorreu em $2003^{7}$. Por outro lado, uma série de elementos de natureza institucional, de estrutura e mesmo de política econômica podem ter efeito sobre esta variável. No primeiro caso, poderíamos elencar uma eventual mudança na inserção geoeconômica ou geopolítica como entrada em algum acordo de comércio bilateral ou mudanças relevantes na estrutura legal do comércio exterior; no segundo, uma eventual maturação de algum projeto de mudança produtiva associado a uma melhoria da inserção externa. O caso clássico de um evento dessa natureza foi a maturação dos investimentos do II PND na década de 1980 que trouxe uma importante melhora das contas externas a partir de 1984. Finalmente, em relação à decisão de política de econômica doméstica, a variável que se associa diretamente ao comércio exterior é a taxa de câmbio efetiva (podendo ser levado em consideração, inclusive, algum subsídio à exportação). Neste caso, no curto prazo, objeto desta nota, uma desvalorização cambial poderia ter efeitos sobre exportação em setores cujos custos salariais fossem mais relevantes (intensivos em trabalho) e, obviamente, desde que os dados empíricos de elasticidade de comércio exterior respeitassem a condição de Marshall Lerner ${ }^{8}$.

Numa perspectiva macroeconômica, entretanto, como é sabido, as exportações tem, em relação ao crescimento, um duplo papel: por um lado, afetam diretamente a demanda agregada e por outro, ao melhorar as contas externas, reduzem a restrição externa abrindo espaço para uma maior expansão de gastos domésticos sem forte deterioração da conta corrente (Medeiros e Serrano, 2001).

Estamos mais interessados aqui em examinar o primeiro efeito. Assim, temos que atentar para quatro efeitos: a evolução do quantum, preço, composição e câmbio. $O$ efeito sobre a demanda decorre do aumento da renda em moeda local, e secundariamente no setor cuja expansão da exportação ocorreu, ou seja, o efeito multiplicador das exportações. Tal impacto sobre a demanda resulta de uma combinação de fatores: aumento na demanda externa (seja pelo crescimento da renda dos importadores e/ou ganhos de competitividade do país exportador), variação de preços internacionais e variação do câmbio. 0 Gráfico 6 mostra que no período no Brasil, estas condições nem sempre foram coincidentes.

\footnotetext{
7 Bastos e Lara (2015) mostram como a expansão das exportação de commodities, a partir de 2003, contrabalançaram as políticas contracionistas domésticas neste mesmo ano, ainda que tenham sido incapazes de evitar uma expressiva redução da taxa de crescimento do PIB. O texto explora a hipótese que a percepção equivocada em relação as medidas contracionistas, de certa forma "mascaradas" por evento não esperado internacional, sejam um dos motivos para a doção das políticas macroeconômicas, que se revelaram desastrosas em 2015.

${ }^{8}$ No curto prazo deve-se lembrar que a combinação de aumento do volume das exportações deve compensar a eventual redução dos seus preços, que as tornariam mais competitivas, a conhecida Curva J. Num médio prazo Freitas, Ferrari e Filho (2013) mostram que mudanças cambiais poderiam tornar competitivos setores com maior elasticidade renda os quais, endogenamente, elevariam sua participação no total das exportações dada sua maior taxa de crescimento. Entretanto, este seria um caso de médio prazo, qual seja o estabelecimento de setores industriais que passariam a ser mais competitivos no mercado internacional. Tal processo de melhoria da inserção internacional estaria fora do escopo de uma análise de conjuntura.
} 
Gráfico 6: Exportações Totais (Brasil) - Índice (2006 = 100 para quantum e $2008=100$ para valor)

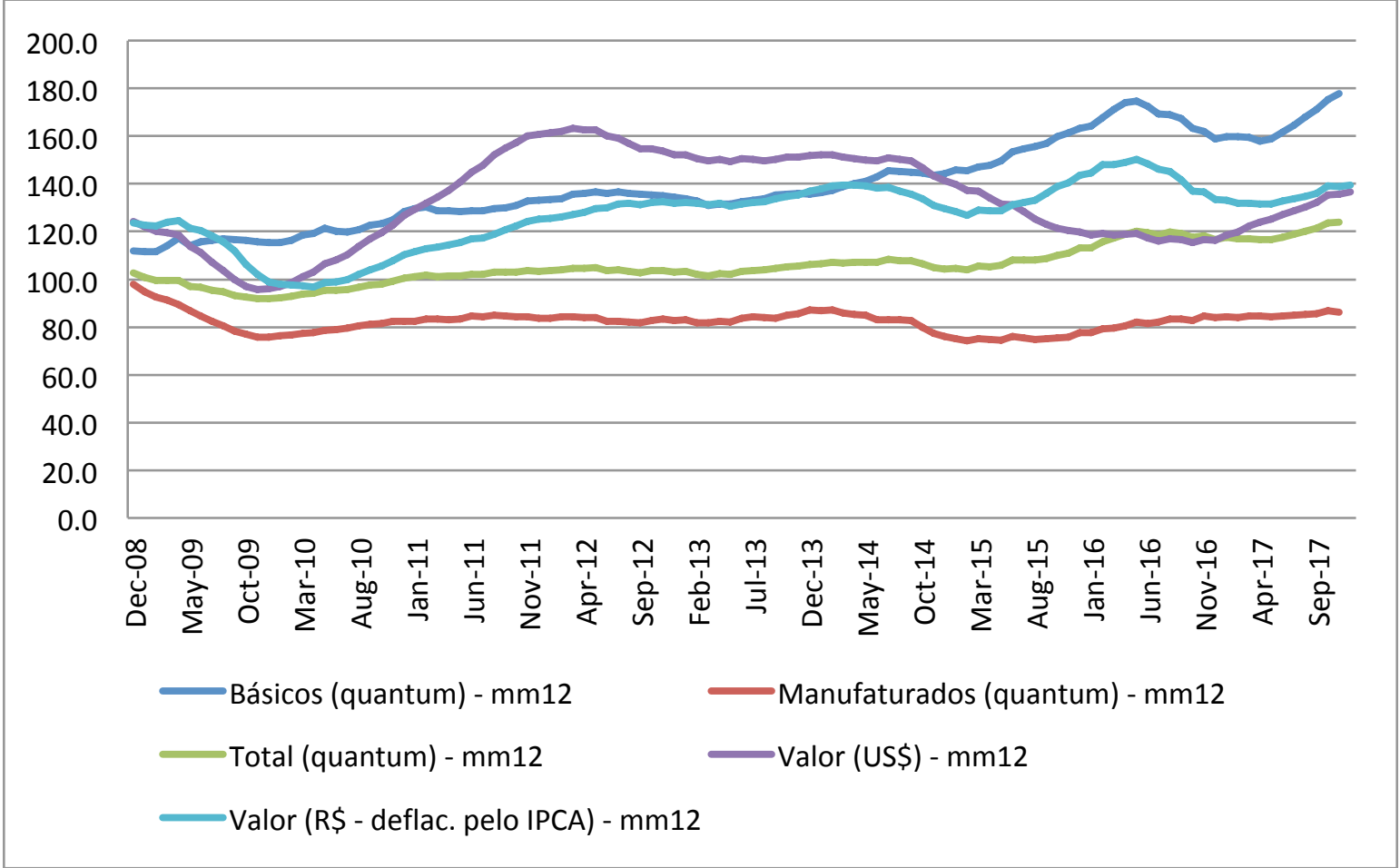

Fonte: IPEADATA. Elaboração própria

A queda de preço das exportações brasileiras (medidas em reais) fez com que esse componente autônomo contribuísse negativamente para a demanda agregada entre 0 segundo semestre de 2014 e primeiro semestre de 2015. A forte desvalorização do câmbio nominal a partir de 2015 acabou por provocar uma expansão das exportações medidas em reais fazendo delas um componente de expansão da demanda autônoma, embora sem compensar na mesma proporção a queda da demanda interna devido a sua baixa participação no PIB. A partir de 2016, o aumento das exportações em reais é puxado, dessa vez, por aumento do quantum, influenciado pela safra agrícola, e recuperação dos preços. Esses efeitos positivos, contudo, foram contrabalanceados por uma valorização do câmbio, reduzindo o ritmo do impacto positivo exercido pelo setor externo.

Os bens manufaturados têm um comportamento bastante estável (que aliás perdura desde 2009), com uma pequena redução a partir do final de 2014 e uma também modesta recuperação a partir de 2016, e relativa estagnação em 2017. Ou seja, a desvalorização cambial em termo nominais que ocorreu de forma mais pronunciada entre julho de $2014 \mathrm{e}$ Janeiro de 2016 (82,2\%) não foi capaz de compensar a deterioração dos termos de troca no período o que, combinado com uma expansão medíocre do quantum de exportações, principalmente de manufaturados, resultou numa queda da receita com as exportações, reforçando as fortes medidas recessivas pós 2015.

Esses dados são consistentes com o papel relevante das exportações para o resultado do PIB do primeiro trimestre vistos anteriormente (Gráficos 1, 2 e 3). Entretanto, cabe indagar se tal desempenho, ou seja, uma manutenção de taxas de crescimento, ou mesmo sua aceleração, em reais, compõe um cenário, plausível. 
Inicialmente, independente da avaliação de curto prazo quanto ao efeito do câmbio sobre exportações ${ }^{9}$, é muito pouco provável que o Banco Central inicie uma rodada de redução de juros a ponto de estimular uma persistente desvalorização cambial. A atual administração do BACEN além de colocar a política anti-inflacionária como meta a ser ferrenhamente perseguida, tem que contar com uma gestão de política econômica em relação a preços administrados bastante agressiva repassando de forma direta choques de custos $^{10}$. Logo, é difícil esperar que desvalorizações cambiais estejam num horizonte plausível de política econômica ${ }^{11}$ e assim o crescimento em reais da renda dos exportadores impactando a demanda doméstica. Também, uma elevação persistente seja da demanda externa em termos de quantum das commodities ou de seus preços, não parece em linha com as previsões de evolução da economia mundial ${ }^{12}$.

Gráfico 7: Produção x Exportações de Veículos - $2014=100$ (com aj. sazonal)

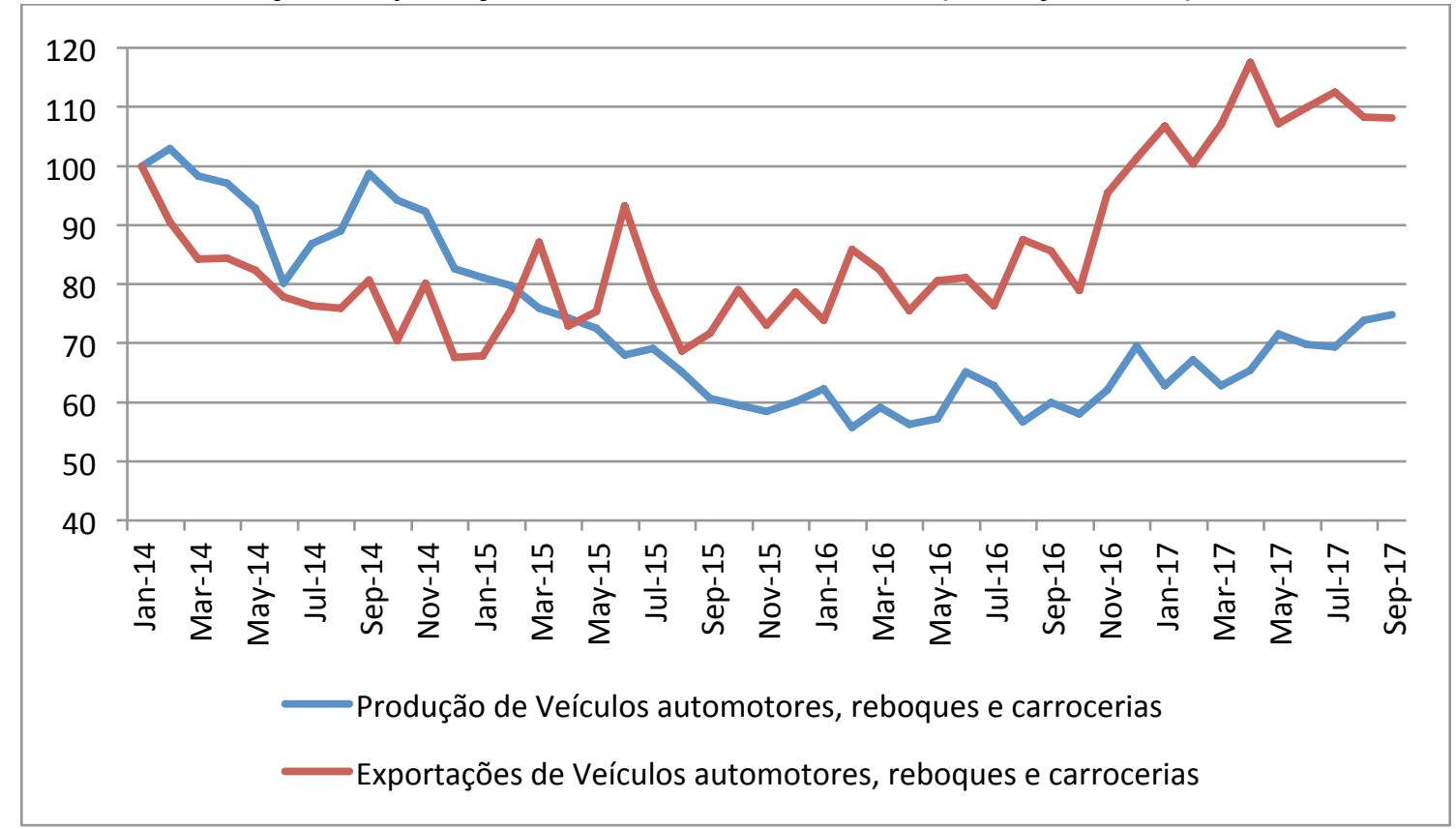

Fonte: Funcex e IBGE. Elaboração própria.

Chama a atenção no Gráfico 7, a recente elevação das exportações de material de transporte sem crescimento equivalente da produção, o que aponta para a exportação estabilizando a produção dado um consumo doméstico deprimido. Este comportamento das

\footnotetext{
${ }^{9}$ Como mencionado anteriormente no curto prazo para que esse efeito seja positivo em termos de balanço de pagamento é necessário que algumas condições de natureza empíricas sejam satisfeitas.

${ }^{10}$ Esta política diverge bastante da adotada no governo Dilma Rousseff quando os preços administrados foram usados sistematicamente para conter a inflação (Summa e Braga, 2014). A "correção" de tais preços defasados foi um dos fatores que contribuiu para a depressão econômica iniciada em 2015.

${ }^{11}$ Uma nota "positiva" do baixo crescimento é uma natural melhora na balança comercial e assim das transações correntes. Este fato associado a persistente política monetária expansionista dos EUA deixam qualquer possibilidade de uma crise cambial praticamente inexistente. Mesmo uma possível moderada elevação da prime rate americana, que poderá ocorrer em 2018, não parece que terá capacidade de alterar substancialmente a situação de financiamento externo.

${ }^{12}$ Segundo o Trade and development Report de 2017 da UNCTAD "World trade is likely to pick up this year from its very sluggish performance in 2016, but there are doubts about the sustainability of the export surge from emerging markets that underlies this improvement. Given weak worldwide demand, global trade is unlikely to serve as a broad stimulus for growth, other than for particular countries that benefit from special circumstances." (p. V)
} 
exportações não parece decorrer de nenhum ganho expressivo de competitividade e nem cambial $^{13}$, ou seja, parece derivar de estratégias das grandes firmas oligopolistas do setor cuja sustentação no longo prazo careceria de uma tendência sustentada de expansão.

Ainda no front externo, cabe especular, sobre uma expectativa realista favorável que decorre da possível expansão da produção de petróleo e elevação do seu preço ${ }^{14}$. De qualquer forma, neste caso, o efeito composição das exportações tem que ser levado em consideração. É sabido que o setor tem um baixo impacto em emprego e na atual conjuntura política não está claro se a Petrobras irá investir mais em termos de criação de nova capacidade e se o investimento das operadoras internacionais, que vem crescendo recentemente sua participação, terão conteúdo importado muito elevado, que represente vazamentos da demanda para o exterior.

Em resumo, no que diz respeito à demanda externa não se pode esperar, a partir dos dados e perspectivas correntes, que exerça uma força de empuxo expressiva em termos de crescimento do produto.

\subsection{Consumo: salários e crédito}

Até pela sua dimensão, um componente central a ser examinado é o consumo, que inclusive como vimos na seção anterior, teve crescimento no segundo e terceiro trimestres de 2017. Para examinar o consumo é preciso dividi-lo em dois componentes: o induzido que depende da folha salarial (elevação tanto do emprego como do salário) mais transferências do governo e do autônomo, ou seja, do consumo a crédito.

Já observamos que a folha salarial se elevou e aqui encontramos um daqueles elementos institucionais que certamente colaborou para a economia chegar a um piso de nível de produto. Este piso foi decorrente de uma inércia institucional sob a forma de reajuste do salário mínimo regido pelo pico real do ano anterior e um ganho do crescimento real do PIB de dois anos anteriores ${ }^{15}$. Em 2017, o reajuste de 6,48\% (considerando o INPC de 2016) representou um aumento médio real significativo neste ano, uma vez que a inflação acumulada em 12 meses gira em torno de $2,70 \%$, resultado que teve como fator positivo a política de valorização cambial do $\mathrm{BCB}$, explicitando a relação entre essa variável, salário real e consumo. Ou seja, como pode-se observar no Gráfico 8, ainda que o PIB não cresça, com uma inflação que se reduz o ganho de salário médio dá um efeito positivo sobre o consumo induzido ${ }^{16}$, principalmente num primeiro momento de salário real de pico.

Em termos de renda extra mercado, através das transferências da previdência, como será visto mais a frente, o reajuste do salário mínimo tem um segundo efeito sobre o consumo. Porém a elevação do salário mínimo, per se, tem efeito once and for all em termos de consumo. Exerceria um efeito dinâmico caso fosse capaz de afetar o mercado de trabalho através de um aquecimento do mesmo que levasse a rodadas de reajuste real do salário ou o investimento, componente que será melhor explorado abaixo. Ou seja, se pode representar

\footnotetext{
${ }^{13}$ A taxa de câmbio real após um ciclo de desvalorização iniciada em 2015 voltou aos índices de 2014, valores reconhecidos como não exatamente "competitivos" pela maioria dos autores. Talvez uma referência.

${ }^{14}$ A recente maturação dos investimentos em exploração na camada do pré-sal e aumento da produção da Petrobras reforçam a hipótese de aumento da produção. Já o preço do barril de Petróleo Brent, teve crescimento de 35\% no período entre os meses de novembro de 2017 e 2016.

${ }^{15}$ Conforme Lei $n^{\circ} 13.152 / 2015$, aprovada ainda no governo Dilma. Caso não seja alterada, esta Lei definirá os reajustes até 2019.

${ }^{16}$ Sobre o impacto do salário mínimo sobre a estrutura de salários, ver Medeiros (2015).
} 
um piso para o produto, o comportamento em 2017 do salário mínimo não pode ser entendido como um componente de dinamização da demanda em $2018^{17}$.

\section{Gráfico 8: Salário Mínimo Real x Rendimento médio real (PME antiga)}

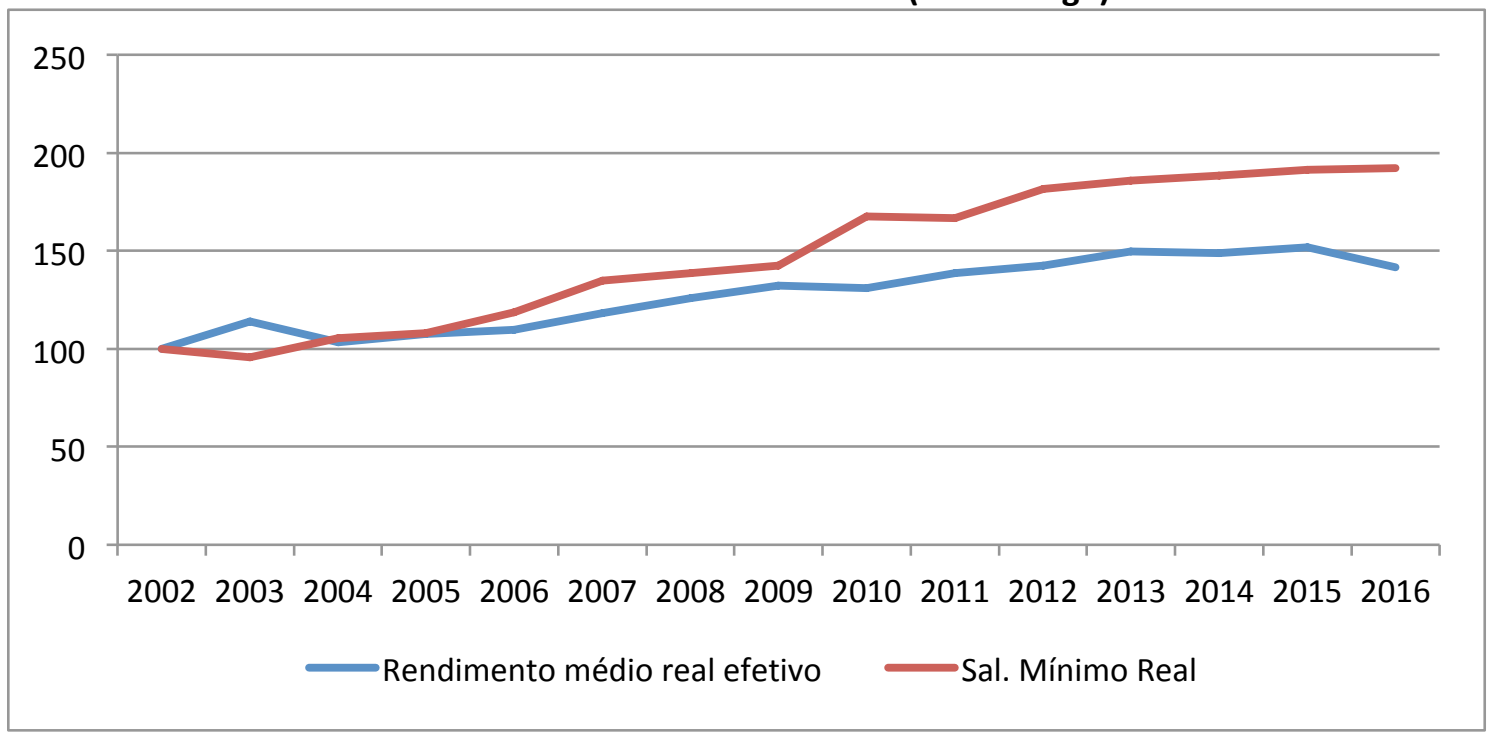

Fonte: IBGE e IPEADATA. Elaboração própria.

Quanto a expansão creditícia, até outubro de 2017, pode-se observar no Gráfico 9 uma modesta recuperação frente aos resultados de 2016, no que tange à concessão de crédito às pessoas físicas, mas estagnação no crédito às pessoas jurídicas.

Gráfico 9: Concessão de Crédito - R\$ Bilhões (a preços de Nov/17)

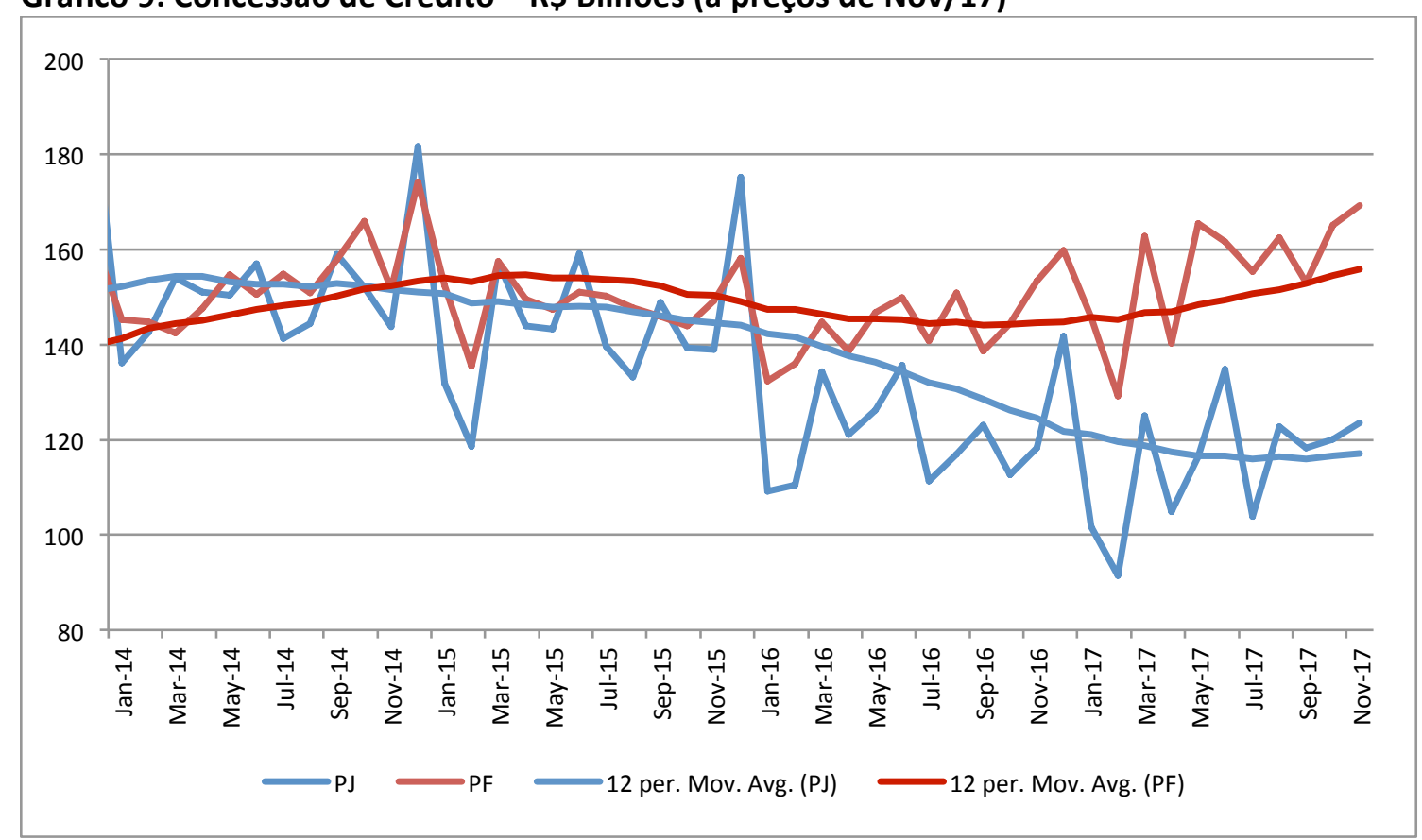

Fonte: $\mathrm{BCB}$. Elaboração própria

Esse resultado é esperado posto que nenhum elemento, o qual poder-se-ia elencar como relevante para uma mais forte expansão do crédito, se fez presente no período.

\footnotetext{
${ }^{17}$ No próximo ano, o reajuste levando-se em conta a inflação de 2017 ficará, provavelmente, abaixo da inflação esperada para 2018.
} 
Pelo lado da oferta, ou das condições de acesso ao crédito, nenhuma inovação financeira de monta (como a expansão do crédito consignado em 2004) ou redução substancial do spread foi percebida.

Pelo lado da demanda, apesar de uma recuperação da folha salarial, esta não parece ter uma dimensão capaz de alavancar um novo ciclo de expansão creditícia. Aliás, esse parece ter sido exatamente uma das questões que explicaram a desaceleração durante o segundo governo Dilma Rousseff: o estancamento da expansão de crédito e com isso a redução das taxas de crescimento do consumo autônomo. Ainda que as razões para tal comportamento não estejam ainda totalmente compreendidas, certamente algumas das razões que podem ser listadas são: a) a alta taxa de juros paga pelos tomadores de crédito de pessoas físicas, inferior à taxa de crescimento de sua renda; b) o decrescimento da taxa de geração de empregos formais e consequentemente da folha de salário (embora esta variação continuasse positiva até 2015) tornando o diferencial de crescimento renda e juros mais negativo; e c) elevação da inadimplência ${ }^{18}$.

Assim, uma moderada retração da demanda por crédito em 2015 (partindo de uma base já deprimida) não foi capaz de provocar uma desalavancagem que pudesse indicar o início de um novo ciclo expansivo de crédito. Vale anotar que, neste caso, a variável em nível tem relevância sobre o valor da taxa: valores muito baixos de comprometimento da renda por crédito (ou relação crédito $\mathrm{PIB}$ ) num primeiro momento podem garantir uma taxa de expansão muito elevada do crédito, o que é menos provável numa economia cuja relação de endividamento sobre PIB (ou renda do trabalho) é mais elevada.

Um dado que acompanha esse quadro de moderada evolução positiva é própria inadimplência das pessoas físicas apresentou uma melhora entre novembro de 2016 e 2017, caindo de $4,1 \%$ para $3,8 \%$ do total das operações, segundo dados do Banco Central.

Entretanto, outra característica presente no forte ciclo expansivo de crédito a partir de 2004 não parece estar presente no atual momento, além das questões relativas ao nível inicial de endividamento e da falta de uma perspectiva de sólido crescimento de salário e renda. Também não parece haver no horizonte de curto prazo propostas para possíveis inovações financeiras. Como se sabe, no ciclo de 2004 a concessão de crédito consignado teve papel importante no início do ciclo e que, posteriormente, foi reforçado pela forte ampliação do mercado formal de trabalho, e elevação da folha salarial.

O que se apresenta como panorama de curto prazo é exatamente o inverso deste quadro. A reforma trabalhista, aprovada pelo Congresso em 2016, permitirá relações de trabalho mais flexíveis e mesmo a previdência (outra fonte de expansão do crédito consignado) vem sendo alvo de propostas de reformas que limitariam os seus benefícios. Ou seja, menos empregos formais e beneficiários da previdência implica menos consumidores elegíveis a tomarem credito do sistema financeiro. É claro que essa é uma característica estrutural do sistema financeiro brasileiro. Nos EUA, por exemplo, o sistema financeiro se expandiu para fornecer crédito a tomadores subprime num movimento que, como mostrou a crise de 2008, não está livre de seus percalços.

É de se perguntar se o sistema financeiro brasileiro caminha para a mesma trajetória institucional norte americana. No presente momento tal cenário não é provável, e o que se tem são práticas usais mais restritivas em relação à definição de tomadores elegíveis.

Há que se notar, no que concerne o consumo também, que apesar do discurso que em alguns momentos se aproxima da ideia de contração expansionista do atual governo, uma

\footnotetext{
${ }^{18}$ Esse fenômeno atingiu fortemente as empresas, como reflexo da queda do faturamento em decorrência da retração do nível de atividade.
} 
decisão expansionista de política pública, a liberação do resultado do FGTS (MP nº 763/2016) para contas inativas, teve o impacto esperado, e representou uma injeção de poder de compra de cerca de $R \$ 44$ bilhões, segundo dados oficiais ${ }^{19}$. Não há disponível dados abertos sobre o direcionamento desse dispêndio, mas tendo sido esses recursos utilizados para pagamento de dívidas bancárias (abrindo limite de crédito para essas pessoas físicas ${ }^{20}$ ) ou para consumo, seu efeito sobre é positivo em termos de expansão do produto via consumo.

Por todas as razões elencadas acima, assim como nas exportações, a expansão autônoma da demanda via consumo a crédito, apesar de provavelmente já ter batido no seu piso, como atesta a leve recuperação de crédito tanto de estoque quanto de novas contratações em 2017, não aponta como um elemento de forte expansão no futuro próximo. Já uma injeção de poder de compra como na liberação do FGTS, equivalente do ponto de vista macroeconômico a transferências do setor público (embora seja um fundo privado e não tenha reflexo sobre as contas públicas), não deve se repetir na mesma proporção em $2018^{21}$.

Gráfico 10: Concessões de Crédito Imobiliário (Total) - R\$ Bilhões (a preços de Nov/17)

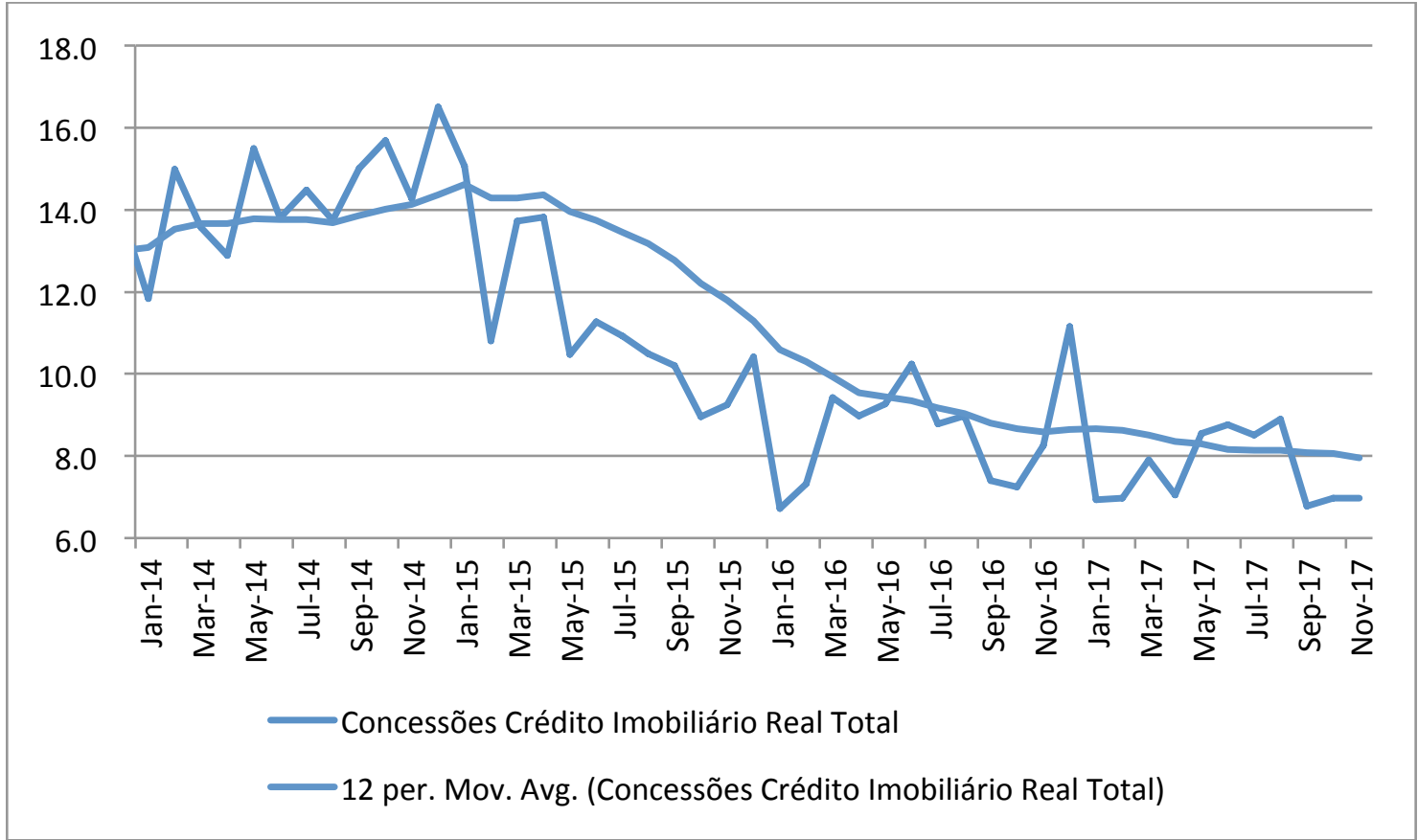

Fonte: BCB. Elaboração Própria

A construção civil, outro componente de demanda autônoma, parece se enquadrar em comportamento semelhante aos componentes descritos até aqui. Um quadro de estabilidade e/ou modesta recuperação, dependendo do indicador analisado, e mesmo da localização geográfica. Como o setor de construção civil é fortemente ligado à concessão de crédito é interessante examinar esta variável. Como esperado, no Gráfico 10, temos uma forte queda que se inicia em 2015 e um panorama de estagnação em 2017. Nas subseções que serão

\footnotetext{
19 https://www.nexojornal.com.br/expresso/2017/08/07/Qual-o-resultado-do-programa-de-saques-doFGTS.

${ }^{20}$ De fato a inadimplência para Pessoas Físicas se reduz em 0,2 p.p. durante o período de saques do FGTS (entre maio/17 e junho/17).

${ }^{21}$ Por meio da MP no 797/2017, o governo autorizou a liberação para saques de cotas do PIS/PASEP para homens (acima de 65 anos) e mulheres (acima de 62 anos). O Governo estima um saque de cerca de R\$ 15,9 bilhões, segundo anúncio oficial. Essas liberações ocorrerão até dezembro de 2017 (http://www.brasil.gov.br/economia-e-emprego/2017/10/governo-inicia-calendario-de-pagamento-dopis-pasep). Esse valor representa menos da metade do saldo liberado pelo FGTS.
} 
discutidos os gastos públicos e os investimentos privados, veremos ainda outros indicadores que apontam no mesmo sentido de estagnação nos gastos em construção civil, após a forte queda de 2015 e 2016.

Em resumo, como o consumo a crédito e, ademais, todo o quadro até agora descrito, na construção civil tem-se uma trajetória de estagnação com leve recuperação no segundo semestre de 2017. Especificamente neste caso, há um fator de política econômica que contribuiu para o mau desempenho do setor. Uma parcela muito expressiva, superior a $60 \%$ das vendas e lançamentos de imóveis estão associados ao programa Minha Casa Minha Vida, programa esse, que como todos os gastos discricionários do governo federal tiveram uma forte redução, como se verá na subseção seguinte.

\subsection{Gastos Públicos}

Outro componente da demanda autônoma que temos que analisar é o gasto público. Neste caso existe uma garantia institucional para que este não venha a se tornar um vetor de recuperação da economia, uma vez que a nova Emenda Constitucional 95/2016 proíbe que haja uma expansão do total de gastos em termos reais de um ano para o outro. Essa, aliás, é uma questão que não pode escapar ao economista que queira avaliar as perspectivas de crescimento futuro da nossa economia. No período recente, desde a estabilização do Plano Real (que podemos considerar uma mudança relevante a ponto de se estabelecer um quebra estrutural), a economia brasileira vem registrando taxas de crescimento que oscilam em torno de $3 \%{ }^{22}$ com uma taxa real de crescimento média do gasto público federal de cerca de $6 \%$ (entre 1998 e 2014). Se essa taxa cair a zero, haverá um impacto negativo direto sobre a taxa de crescimento, que só seria compensada caso a) houvesse uma relação direta entre variação dos gastos (e não déficit, já que este é residual, e pode até subir com a redução dos gastos) e juros básicos da economia e b) uma forte elasticidade entre juros e investimento.

Ambas as afirmações são alvo de extensa controvérsia e não tem sustentação empírica inequívoca nas diversas estimativas empíricas disponíveis ${ }^{23}$. Tendo em vista ainda o momento recessivo do ciclo econômico que passa a economia brasileira, já com juros reais em queda, a expectativa mais concreta no curto prazo é que a redução da taxa de crescimento do gasto público a zero reduza ainda mais a trajetória de crescimento da economia ano médio prazo.

Em uma análise conjuntural, é importante saber se o gasto público está tendo, ou não, um impacto claramente negativo na trajetória corrente do PIB. Nota-se na tabela 1, que a partir de 2015, as despesas primárias do Governo Central (que exclui somente as estatais e os governos regionais) apresenta forte redução no seu crescimento e cresce, em termo reais, no biênio 2015 e 2016, em média, 1,3 \% a.a.

Chama a atenção na Tabela 1, a forte contração das despesas discricionárias, resultado de um forte ajuste fiscal iniciado em 2015, que tiveram grande impacto nos investimentos do PAC e do Minha Casa Minha Vida. Esse corte tem forte efeito negativo na demanda agregada e no crescimento por se tratar de um importante componente de gasto autônomo não gerador de capacidade produtiva. Dessa forma, conjugando-se com o dado já visto relacionado à contração do financiamento imobiliário, a contração dos investimentos públicos do governo foi outro importante fator preponderante para a contração dos gastos em construção civil. Não menos relevante foi também o corte nas demais despesas discricionárias, em particular dos

\footnotetext{
22 Esse é o valor de 1995 a 2014. Ela foi superior no período mais expansivo que vai de 2004 a 2011, 4,4\%, e inferior entre 1995 e 2003, 2,3\% e ainda pior pós a desaceleração de 2011, sendo esta taxa de $1,8 \%$ entre 2012 e 2014.

${ }^{23}$ Para um resumo da discussão e aplicação à economia brasileira, ver Orair, Siqueira e Gobetti (2016).
} 
Ministérios da Saúde e Educação, que também contraíram fortemente gastos de custeio e de investimento no seu setor.

As despesas em subsídios, majoritariamente destinadas a subsídios para operações de crédito, também foram alvo de forte redução (com exceção de 2015, quando ocorreu forte aumento para pagamento pelo Tesouro Nacional dos saldos existentes junto aos bancos públicos). Nesse caso, é também um fator que, ao encarecer o crédito, pode ter algum efeito negativo sobre os gastos autônomos.

Finalmente, as despesas com transferências sociais (benefícios previdenciários e BPC LOAS) tiveram crescimento. Esse crescimento pode ser explicado pelo aumento do salário mínimo, como já mencionado anteriormente, e também pelo aumento das despesas decorrente do anúncio da reforma da previdência, que levou muitas pessoas a anteciparem o seu pedido de aposentadoria. Assim, como discutido na subseção sobre o consumo, as transferências contribuíram positivamente para o incentivo ao consumo e reforçaram a inércia institucional que contribuiu para que a economia brasileira encontrasse um piso em 2017.

Já a despesa com pessoal e encargos, que se encontrava estável até 2016, teve um substancial aumento em 2017, quando entraram em vigor alguns dos reajustes aprovados pelo governo do presidente Temer em 2016. Entretanto, para se ter uma ideia mais precisa sobre seu impacto sobre os componentes de demanda, seria necessário atentar para a distribuição desses pagamentos por faixa de renda, ou seja: estando concentrados tais aumentos em categorias cuja remuneração já é mais elevada, é provável que tal impacto seja bem menos intenso que o que decorreu da elevação com os gastos de previdência

A nível federal, em síntese, como vem sendo interpretada a emenda dos tetos do gasto, com o teto virando também piso, a contribuição das despesas públicas tende a ser nula em termos de impacto sobre o produto agregado. Olhando os dados desagregados essa convergência teto/piso ocorreu, basicamente, pela expansão do gasto de previdência, já mencionada. Novamente, restrições propostas a dispêndios previdenciários que possam a ocorrer em função de mudanças constitucionais terão impacto direto sobre o consumo e consequentemente sobre o produto.

Tabela 1 - Despesas Primárias do Governo Central

\begin{tabular}{|l|r|r|r|r|}
\hline & \multicolumn{5}{c|}{ Var. (\%) Real } \\
\hline Despesa Total & $\mathbf{2 0 1 4}$ & \multicolumn{1}{c|}{$\mathbf{2 0 1 5}$} & \multicolumn{1}{c|}{$\mathbf{2 0 1 6}$} & \multicolumn{1}{c|}{$\mathbf{2 0 1 7}$} \\
\hline Benefícios Previdenciários + BPC Loas & $6,3 \%$ & $1,9 \%$ & $-0,6 \%$ & $0,0 \%$ \\
\hline Pessoal e Encargos Sociais & $4,0 \%$ & $1,4 \%$ & $7,1 \%$ & $6,1 \%$ \\
\hline Abono e Seguro Desemprego & $1,9 \%$ & $-1,7 \%$ & $-0,5 \%$ & $7,1 \%$ \\
\hline Subsídios, Subvenções e Proagro & $14,4 \%$ & $-19,0 \%$ & $8,8 \%$ & $-7,5 \%$ \\
\hline Outras Despesas Obrigatórias & $-31,4 \%$ & $997,0 \%$ & $-58,3 \%$ & $-23,4 \%$ \\
\hline PAC (exceto MCMV) & $21,5 \%$ & $38,5 \%$ & $-24,0 \%$ & $-8,7 \%$ \\
\hline MCMV & $24,6 \%$ & $-39,7 \%$ & $18,0 \%$ & $-35,6 \%$ \\
\hline Min. da Saúde & $15,3 \%$ & $7,3 \%$ & $-64,3 \%$ & $-61,0 \%$ \\
\hline Min. do Desenv. Social & $7,2 \%$ & $-6,9 \%$ & $6,8 \%$ & $-4,7 \%$ \\
\hline Min. da Educação & $4,9 \%$ & $-10,6 \%$ & $-3,1 \%$ & $0,4 \%$ \\
\hline Outras Despesas Discricionárias & $9,4 \%$ & $-17,6 \%$ & $-2,9 \%$ & $-11,9 \%$ \\
\hline
\end{tabular}

*Dados acumulados até novembro/17 


\subsection{Investimento privado}

É interessante anotar que toda a discussão que foi desenvolvida aqui não tratou do investimento privado, porque, afinal, supondo que este depende das expectativas de demanda não haveria nenhuma razão lógica para sua elevação no curto prazo. Há é claro um componente autônomo do investimento privado não gerador de capacidade, o investimento em construção civil. Como já visto nas subseções relativas ao consumo e gasto público, todos indicadores apontam para um cenário de forte queda dos gastos, até 2016, e de estagnação (mais uma vez um piso) em 2017. O indicador do IPEA de Formação Bruta de Capital Fixo na construção civil, disponível até junho/2017, apresentado no Gráfico 11 reforça o argumento aqui exposto.

Gráfico 11: Indicador IPEA da FBCF - construção civil - índice encadeado - Média 1995 = 100 (com aj. sazonal)

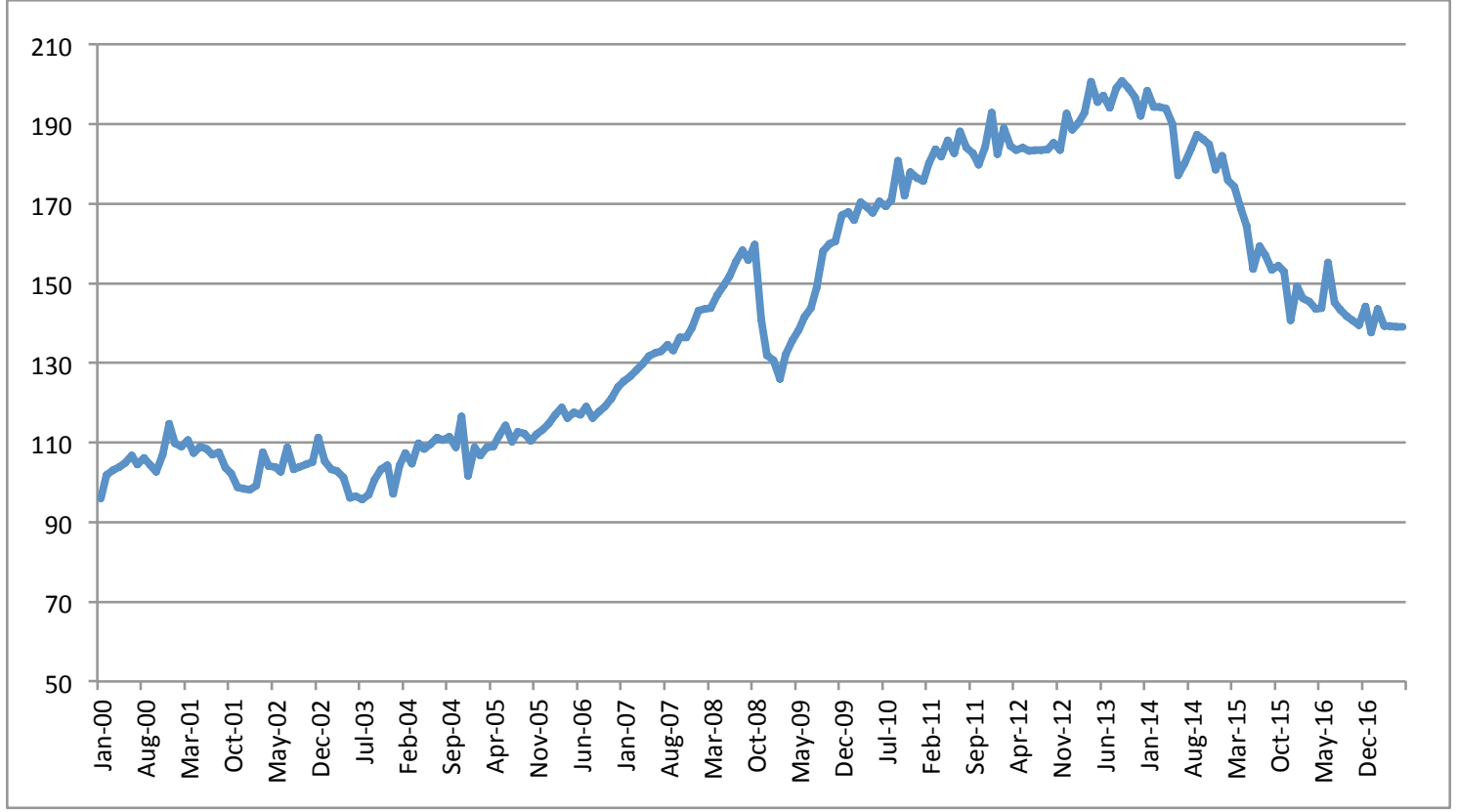

Fonte: IPEADATA. Elaboração própria.

Já o investimento gerador de capacidade produtiva, associado a uma expectativa de demanda, como era esperado, num período de redução acelerada do nível, reagiu decaindo ainda mais que o nível de produto agregado, refletindo o conhecido mecanismo do acelerador do investimento. Esperar algum investimento autônomo, por exemplo, advindo de processo de inovação tecnológica, também seria altamente problemático, tanto pela atual estrutura produtiva da economia brasileira como mesmo pela Lei de Verdoorn, que associa a inovação ao próprio crescimento da economia.

Uma suposta retomada dos investimentos trazida por uma maior confiança cuja posse do vice-presidente Temer incutiria no mercado, mostrou-se um argumento totalmente desprovido de base real, posto que sua base teórica, mesmo dentro da ortodoxia marginalista é de validade duvidosa. Segundo esta teoria, a nova administração, ao provocar uma redução do prêmio de risco expresso nas taxas de juros futuras, poderia exercer algum efeito positivo reduzindo de forma substancial os juros e contando com uma forte elasticidade juros do investimento, mesmo frente a uma expressiva capacidade ociosa. No entanto, a tão esperada retomada via melhora das expectativas e retomada dos investimentos privados não se concretizou na conjuntura atual. Assim como em outros momentos da nossa economia, a 
recuperação esteve muito mais associada à expansão do consumo provocada seja pela elevação do salário mínimo, seja pela injeção de poder de compra do setor público (FGTS) ${ }^{24}$.

Observa-se que, após 15 trimestres de quedas, o dado de Formação Bruta de Capital Fixo apurado pelas Contas Nacionais do IBGE apresentou variação positiva de $1,6 \%$ na comparação entre o terceiro e o segundo trimestre de 2017. Como hipótese, a provável redução do ritmo de queda dos investimentos pode estar associada a algum efeito acelerador decorrente da leve recuperação do nível de atividade da economia. Ao se olhar o grau de utilização com ajuste sazonal, observa-se uma recuperação do grau de utilização em 2017 em relação à 2016. Há que se notar, entretanto, que essa recuperação por ter se iniciado no primeiro trimestre de 2017, pode estar associada, neste período, ao acúmulo indesejado de estoques já mencionados.

\section{Gráfico 12: Variação (\%) FBCF - Contas Nacionais Trimestrais}

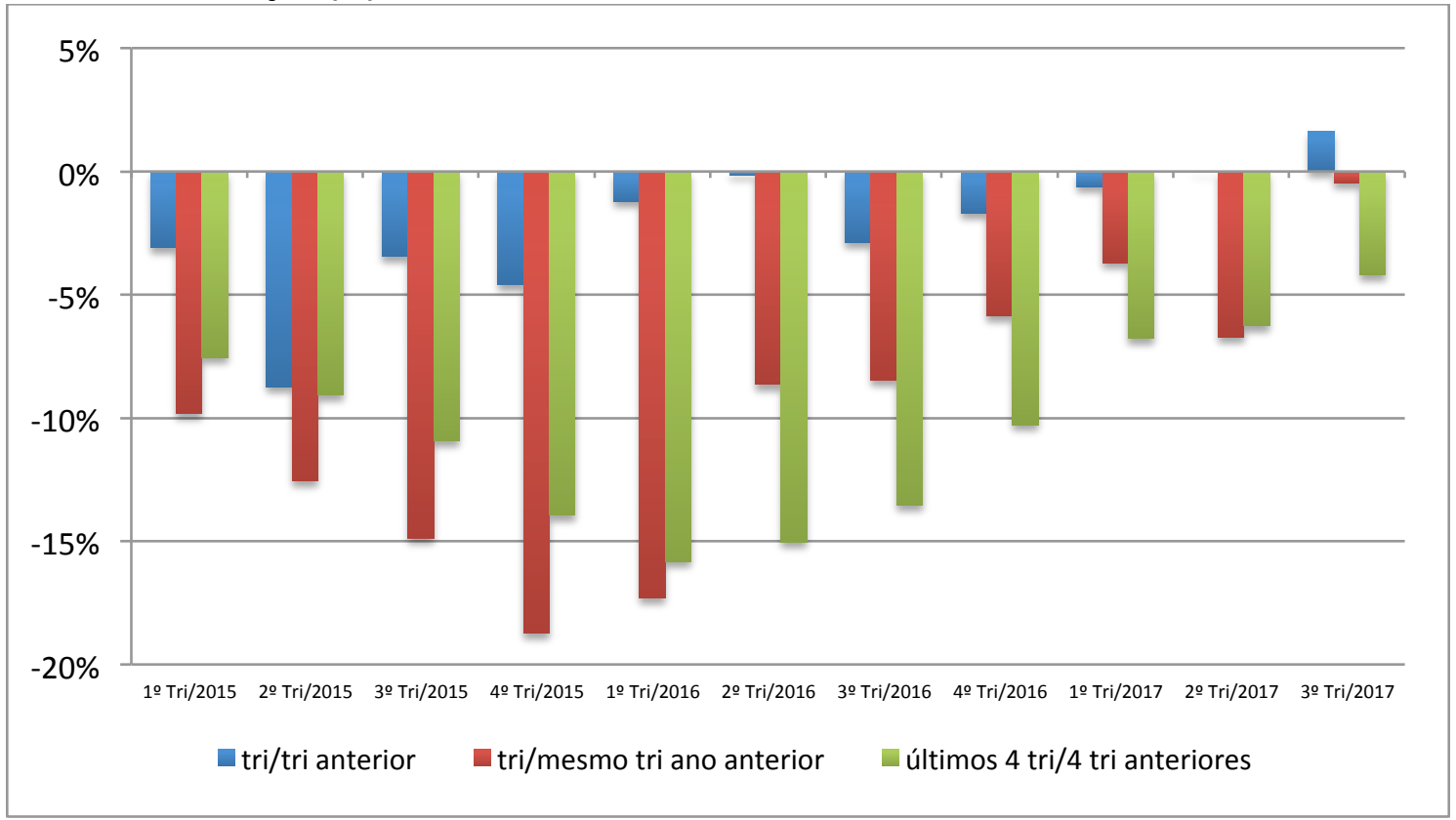

Fonte: IBGE. Elaboração própria.

\footnotetext{
${ }^{24}$ Curiosamente até o Presidente do Bacen acreditava que uma onda de confiança no Governo Temer faria crescer o investimento a despeito de uma demanda deprimida, grande capacidade ociosa e juros estabelecidos pelo próprio Banco Central bastante elevados. Em entrevista ao Jornal Folha de São Paulo revelou sua surpresa com a sequência no comportamento das variáveis de demanda que levou ao fim do processo de queda do produto. Nessa passagem reconhece que sua "crença" estava equivocada ainda que mantendo a suposição que tal "tese" inicial fosse compartilhada por um grande número de economistas: "Há um ano, todos imaginavam que a economia brasileira poderia voltar a crescer a partir do aumento de confiança, que geraria investimentos, renda e consumo. O emprego seria o último a se recuperar. Essa ordem um pouco diferente" http://www1.folha.uol.com.br/mercado/2017/08/1913221-consumo-puxa-recuperacao-lenta-da-
} economia-diz-presidente-do-bc.shtml 
Gráfico 13: NUCl - FGV (com ajuste sazonal)

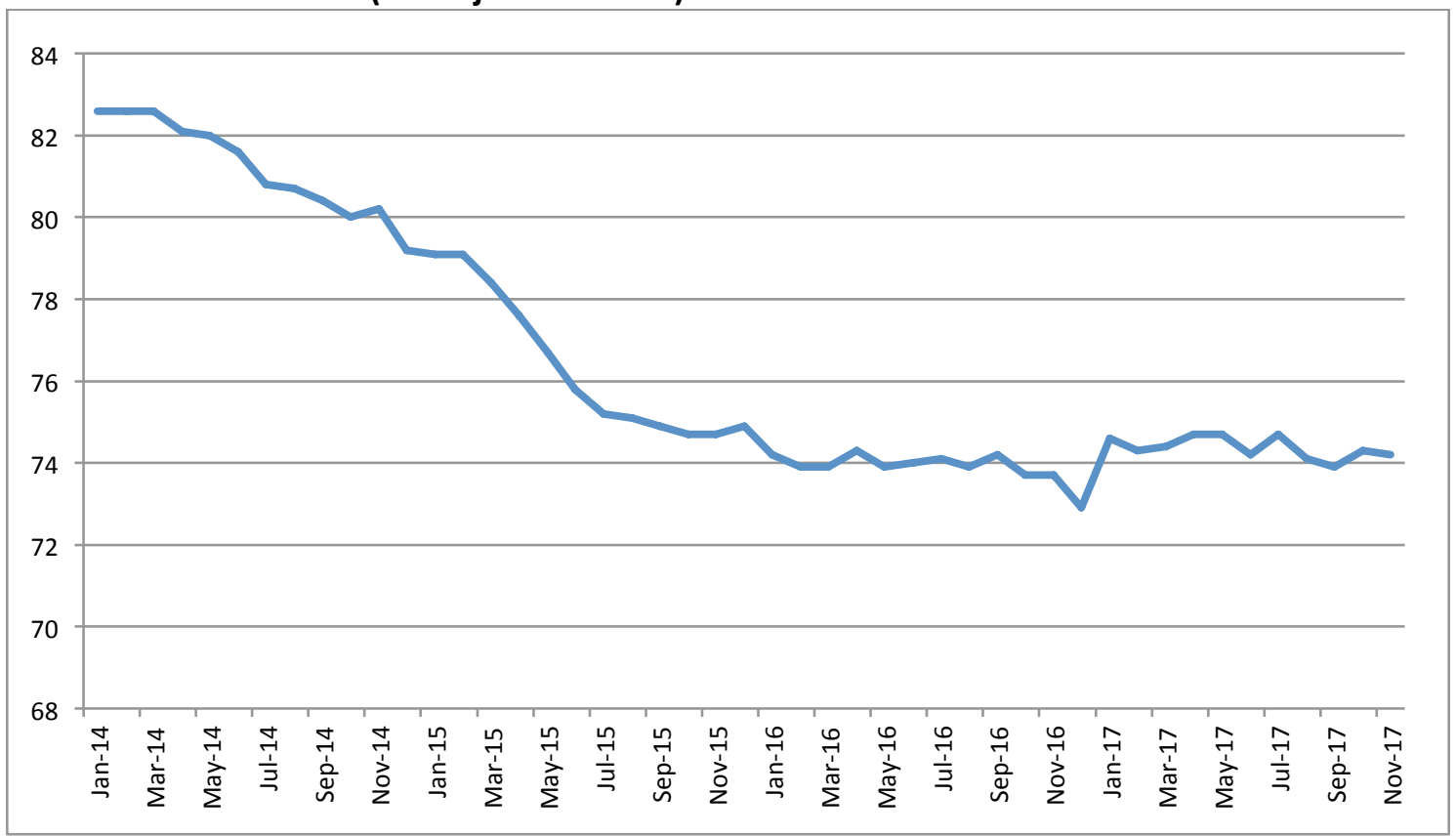

Fonte: FGV. Elaboração própria

\section{Considerações Finais}

Numa economia cujo nível de produto é determinado pela demanda não existiria, em tese, um piso de reversão cíclica numa depressão econômica. Observando, entretanto, os episódios mais intensos de retração do produto, tem-se que em algum ponto se encontra um piso, o que nos sugeriu a existência de um mínimo socialmente tolerável que dependeria de características político institucionais de cada economia.

No caso específico brasileiro foram identificados alguns componentes que responderam pela economia alcançar seu piso. Em primeiro, lugar a existência de uma política de reajuste do salário mínimo, com impactos sobre gastos da previdência que estimularam os gastos de consumo. Esse efeito sobre o consumo também foi favorecido por medidas excepcionais como a liberação do FGTS.

Uma reversão e consumo e do emprego tem uma efeito positivo secundário sobre o próprio emprego. Vale ressaltar que um crescimento desequilibrado dos setores informal e formal indica que frente a uma pequena melhora das condições gerais da economia, os trabalhadores procuraram buscar qualquer atividade, por mais precária que possa ser, como uma pressão por sobrevivência numa economia na qual a rede de proteção social não é tão desenvolvida.

Outro fator de sustentação é o próprio gasto público impactado pela institucionalidade do gasto da previdência, criando um fato que carrega certo grau de ironia: o mesmo gasto que permitiu às autoridades federais apregoarem algum sucesso de política econômica é apresentada como uma das maiores mazelas da economia a serem combatidas.

Ainda que não seja um elemento institucional doméstico a partir de 2017 o setor externo exerceu um importante papel de sustentação da demanda agregada.

Um ponto destacado nesta nota, para estes elementos de demanda agregada, é que, a despeito de terem tido um papel importante no estancamento da queda do PIB em 2017, em nenhum momento, dadas as condições político-institucionais domésticas e estruturais 
internacionais, esses mesmos elementos parecem capazes de puxar um ciclo expansivo mais vigoroso no médio prazo.

As perspectivas das exportações dada a demanda internacional e sem mudanças estruturais relevantes da nossa inserção internacional não parecem garantir uma forte expansão produto. $O$ efeito de expansão do salário mínimo foi de natureza once and for all e as propostas de precarização do mercado de trabalho não autorizam que se tenha grandes expectativas de elevação salarial além de seus efeitos indiretos, via menor formalização, sobre a expansão de crédito. Esta por sua vez está crescendo a ritmo baixo e pode-se descartar uma tendência de aceleração seja pelo próprio baixo crescimento da folha salarial seja pelo spread elevadíssimo dos juros cobrados as pessoas físicas.

Pelo lado fiscal há uma lei definindo que este não será expansionista e reformas regressivas da previdência podem ter efeitos depressivos sobre o consumo privado. Se fora do Brasil vem sendo discutida a necessidade de se repensar a utilização de políticas fiscais ${ }^{25}$ aqui se impôs uma regra que fará cair a participação do gasto público no PIB e assim, provavelmente, deteriorar a oferta já insuficiente de bens públicos. Por outro lado, a experiência brasileira nos últimos anos não parece justificar a esperança de que o ajuste fiscal e a confiança do mercado puxem uma retomada dos investimentos.

Em poucas palavras, o que a literatura internacional vem denominando como "estagnação secular" nos países ricos parece poder atingir em cheio a economia brasileira, a qual, entretanto, tem como fatores socialmente ainda mais complicadores uma estrutura socioeconômica altamente desigual e com boa parte da população vivendo em condições muito inferiores àquelas existentes nos países desenvolvidos.

\section{Referências Bibliográficas}

Auerbach, A. e Y. Gorodnichenko. (2017) "Fiscal stimulus and fiscal sustainability" NBER Working Paper, n. 23789. Disponível em <http://www.nber.org/papers/w23789.pdf> Acessado em 06/12/17.

Bastos, C. P. e Lara, F. M. (2015) “2015: novo 2003?” In: L. Belluzzo e P. Bastos (orgs.) Austeridade para quem? Balanço e perspectivas do governo Dilma Rousseff, São Paulo: Carta Maior, Fundação Friedrich Ebert Stiftung.

Bivens, J. (2016) "Why is Recovery Taking So Long - and Who's to Blame?" Economic Policy Institute.

Freitas, F., Ferrari, M. e Barbosa Filho, N. (2013) "A Taxa de Câmbio Real e a Restrição Externa: Uma Proposta de Releitura com Elasticidades Endógenas", Revista de Economia Politica, v. 33 nำ1, p. 60-81.

Medeiros, C. (2015) Inserção externa, crescimento e padrões de consumo na economia brasileira. Brasília, DF: IPEA. Disponível em <http://www.ipea.gov.br/portal/images/stories/PDFs/livros/livros/20150415_livro_ins ercao-externa.pdf>. Acessado em 06/12/2017.

Medeiros, C. e Serrano, F. (2001) "Inserção externa, exportações e crescimento no Brasil”, In J. Fiori e C. Medeiros (eds.), Polarização Mundial e Crescimento, Petrópolis: Vozes.

${ }^{25}$ Ver por exemplo Auerbach e Gorodnichenko (2017). 
Kalecki, M. (1990, [1943]) "Political Asp ects of Full Employment" In J. Osiatynski (ed) Collected Works of Michal Kalecki, v.1, Oxford University Press.

Orair, R., Siqueira, F. e Gobetti, S. (2016) "Política fiscal e ciclo econômico: uma análise baseada em multiplicadores do gasto público". XXI Prêmio do Tesouro Nacional, Brasília, DF. Disponível

em http://www.tesouro.fazenda.gov.br/documents/10180/558095/2o-lugar-rodrigooctavio-orair-086.pdf/ff2dc598-149a-419d-b95f-fb6e54e10d4f> Acessado em 06/12/17.

Rezende, P. (2009) "The Nature of Government Finance in Brazil," International Journal of Political Economy, 38 (1): 81-104.

Serrano, F. e Pimentel, K. (2016) "Será que "Acabou o Dinheiro"? Financiamento do gasto público e taxas de juros num país de moeda soberana" Disponível em <http://www.excedente.org/wp-content/uploads/2016/03/SERRANO-F.-e-PIMENTELK.-2017-Financiamento-do-gasto-p\%C3\%BAblico-e-taxas-de-juros-REC-2017-1502.pdf>. Acessado em 06/12/2017

Summa, R. e Braga, J. (2014) "Estimação de um modelo desagregado de inflação de custo para o Brasil", IE Working paper , n.14/2014, Instituto de Economia, UFRJ.

Summa, R., Lara, F. e Serrano, F. (2017) "PIB, demanda efetiva e variação de estoques: uma visão pessimista do que já ocorreu em 2017". Disponível em $<$ http://www.excedente.org/blog/pib-demanda-efetiva-e-variacao-de-estoques-umavisao-pessimista-do-que-ja-ocorreu-em-2017/>. Acessado em 06/12/17. 